\title{
Pyrazine Diazohydroxide
}

National Cancer Institute

\section{Source}

National Cancer Institute. Pyrazine Diazohydroxide. NCI Thesaurus. Code C1207.

A congener of pyridine 2-diazohydroxide. Pyrazine diazohydroxide forms DNA adducts via the reactive pyrazine diazonium ion, thereby inhibiting DNA synthesis. ( $\mathrm{NCI04)}$ 